\title{
THE IMPACT OF RISING FOOD PRICES ON FARMERS' WELFARE IN INDONESIA
}

\author{
Albertus Girik Allo \\ Faculty of Economics and Business, Universitas Papua, Indonesia \\ (albertusgirikallo@yahoo.co.id) \\ Elan Satriawan \\ Faculty of Economics and Business, Universitas Gadjah Mada, Indonesia \\ (esatriawan@ugm.ac.id) \\ Lincolin Arsyad \\ Faculty of Economics and Business, Universitas Gadjah Mada, Indonesia \\ (lincolinarsyad@ugm.ac.id)
}

\begin{abstract}
Food prices regularly change due to various factors such as the policy on imports. This paper analyzes the impact of changes in food prices including rice, red onions, and garlic, on farmers' welfare. The Quadratic Almost Ideal Demand System (QUAIDS) was used to estimate the demand function for food commodities, and the Compensating Variation (CV) was used to estimate the impact of price changes both immediately and in the short-term. This study contributes an idea of how the government makes its policies on food prices and imports, and how they provide benefits for farmers in Indonesia. Data were collected from the 2014 National Socio-economic Survey (SUSENAS). The research results indicated that income improvement led to an increase in rice, red onion, and garlic consumption. The dynamics of income, own-price and cross-price elasticity varied, depending on demography, the social economic condition, and the geographic location of the household. The shortterm impact of imported products on welfare changes was larger than the immediate impact.
\end{abstract}

Keywords: food prices, farmers, QUAIDS, compensating variation

JEL Classification: C31, D11, Q11, Q12 


\section{INTRODUCTION}

The inflation rate in Indonesia has fluctuated considerably since the financial crisis in 1997/1998. The highest rate of inflation was recorded in November 2005 (18.38\%), and the lowest was in November 2009 (2.41\%), with an average inflation rate in the period 2003-2015 of $7.13 \%$ (Bank Indonesia, 2016). The inflation in this study focused on the average inflation rate, based on expenditure classifications in the last ten years (2006-2015). The largest contribution to inflation is by fluctuations in the price of foodstuff, by $9.62 \%$ and followed by prepared food, beverage, cigarette, and tobacco by $7.27 \%$. This rate is higher than the average inflation rate at the national level, which is $6.22 \%$ (BPS, 2016). Furthermore, the data show that the inflation rate for non-food groups such as housing, safe water, electricity, and fuel (5.03\%); clothing (5.44\%); medical care (4.61\%); education, recreation, and sports (5.25\%); transportation, communication, and financial services $(3.89 \%)$ are all less than that for food. This condition indicates that an increase in the price of food is much larger than that for non-food items.

Price level stability and the food import policy are two hot issues every year, and they are part of the political issues in Indonesia. A key issue from such policies is whether the price stability or inflation targeting and import policy will have positive or negative impacts on the people's welfare. Both policies can push the price to a higher or lower level. The impact of higher prices on households' welfare depends on the income and expenditure characteristics of the household. For urban households, higher food prices will have a negative impact. The reason is that food items for urban households must be purchased in the market. In other words, urban households are net consumers. For rural households, on the other hand, higher food prices may result in both better and worse impacts, because rural households behave as both producers and consumers. If a rural household produces less food than they need to consume, the household is said to be a net consumer. In this case, higher food prices will boost the household's spending on food. The opposite is true if the household is a net producer. Therefore, the predicted impact of the change in food prices on a household's welfare depends on the household's characteristics, such as its geographic location and the source of its main income (Mellor, 1978).

Based on cross-country data, empirical studies report various impacts of food price changes on households' welfare. Several studies report a positive impact, while others report a negative impact. In Thailand, Deaton (1989) investigated the impact of food price changes on household welfare. He found that a higher food price has a positive impact on households with a medium income level. In Vietnam, a 10\% increase in rice prices results in a positive impact on farmers' welfare, especially those who plant rice (Minot and Goletti, 2000).

Ivanic and Martin (2008) reported that the increase in rice prices reduced poverty in Vietnam in 1998 and 2004; as well as for the period 2007 and 2008 (Hoang and Glewwe, 2011). Barrett and Dorosh (1996) conducted a study in Madagascar and show that an increase in food prices lowered the general level of prosperity of the rural population in Madagascar, especially for low and middle-income households. The opposite also works for highincome households. In Mexico, Attanasio et al.,(2013) found that an increase in food prices affects households' welfare in rural areas, on average by $19 \%$, measured by their average spending on food in 2011.

Several studies conducted in Indonesia indicate that higher prices result in a negative 
impact on household poverty. A study conducted by Ravallion and van der Walle (1991) indicated that a $10 \%$ increase in food prices had an impact on severe poverty in Indonesia. A similar result was reported in the study conducted by Ikhsan (2003). Ikhsan found that, on aggregate, a $10 \%$ increase in rice prices is translated into a $1 \%$ increase for poor households. This higher price level has been creating on equivalent to two million poor households on the Indonesian population. A similar result was reported by McCulloch (2008). A 10\% increase in rice prices improves the welfare of $14 \%$ of the households, while the remaining $86 \%$ suffer a relative loss of income.

The main problem with several studies previously conducted in Indonesia, related to the impact of price changes on the level of household welfare, is that they did not distinguish the households' characteristics. The characteristics allow a limited amount of taste variation across households (Deaton and Muellbauer, 1980). Therefore, this study attempts to fill the gap in the previous studies that were not conducted using consumer and producer prices in the Compensating Variation (CV) model which was expressed by Deaton (1989), and which was adopted by Hoang and Glewwe (2011) in the case of Vietnam.

This study aims to estimate the demand function for food commodities. Specifically, this study aims to analyze the impact of price changes in imported food commodities on farmers' welfare in Indonesia. Data were taken from the 2014 National Socio-economic Survey (SUSENAS), collected by the Indonesian Central Bureau of Statistics (BPS). It is expected that this study can contribute an idea of how the government makes its policies on food prices and imports. These policies will provide opportunities for farmers in Indonesia to improve their welfare.

\section{LITERATURE REVIEW}

\section{Definition of Farmer}

The word "farmer" was used to describe someone who rents a farm used for raising crops or livestock (Dyer, 2007). This concept later evolved into the concept of small or large farmers based on land ownership. The Great Dictionary of Indonesian Language (Kamus Besar Bahasa Indonesia/KBBI) defines farmers as those who cultivate crops. This means that different farmers will provide different data outputs. The Central Bureau of Statistics (Badan Pusat Statistik/BPS) defines farmers as those who commercialize agriculture (food crops and plantations) at their own risk for selling, either as a farmer or a sharecropper (BPS, 2017).

Different definitions of a farmer will result in different numbers of farmers. For example, the use of the term farmer to cover all those engaged in agriculture, regardless of time and the source of income from the off-farm sectors, will generate a biased number of farmers. Combining tenure with a farmer's position in the labor market in rural areas can be used to overcome such problems (Pincus, 1996).

In developed countries, a farmer is a professional who is defined as a person with proprietary crops or livestock and involved in production management of an agricultural business. Accordingly, a person can be categorized as a farmer if the person has a piece of land which produces agricultural products. Meanwhile, people who work and receive wages from the production process are referred to as farm laborers. Sharecroppers are defined as farmers who work the land belonging to others in various ways (e.g., leases, contracts, profit sharing). In addition, there are also small farmers with land holdings of less than 0.25 ha in which the cultivation is done alone or together with members of their family. People working in the 
field or for other people and expect a wage (a peasant) are not included as farmers.

\section{Quadratic Almost Ideal Demand System (QUAIDS)}

The system demand equation has been proposed and applied by economists when analyzing the demand for food commodities in many countries. The frequently-used demand models, among others, are the Linear Expenditure System (LES), Almost Ideal Demand System (AIDS), and Quadratic Almost Ideal Demand System (QUAIDS). The LES model was first introduced by Stone (1954) to drive a certain utility function with budget constraints to get a linear equation of the demand function. The basic assumptions of this model are additivity, homogeneity, and symmetry, which are important for understanding household behavior within the framework of the general equilibrium (Stone, 1954). The Rotterdam model (Theil, 1965) and the translog model (Christensen et al., 1975) are an extension of the LES model by combining homogeneity's assumption and symmetry's assumption.

Deaton and Muellbauer (1980) compared the Rotterdam model and translog model. The result is a new model known as the Almost Ideal Demand System (AIDS). The AIDS model has several advantages compared to the previous models, in that: (1) The AIDS model satisfies continuity in the axiom of choice. (2) On aggregate the AIDS model has been proven, it can be generalized for individual $\mathrm{i}=1,2,3, \ldots, \mathrm{n}$ without involving linear and parallel Engel curves. (3) The AIDS model has consistent functional form, and it is consistent with budget data at the household level. (4) The AIDS model can be easily estimated, which helps avoid the need for estimating nonlinear demand functions.

(5) The AIDS model can be applied for testing homogeneity and symmetry assumptions by restricting the determined parameters (Deaton and Muellbauer, 1980).

Banks and Lewbel (1997) argued that the AIDS model had two weaknesses, namely: (1) The previous empirical demand model, which was estimated for many commodities, AIDS model was not able to describe accurately in terms of the different behavior of cross-income levels and cross-region. (2) The relationship between purchasing a commodity and consumer expenditure (the Engel curve) was not linear but quadratic on the logarithm of income. In order to overcome the weaknesses of the AIDS model, Banks and Lewbel (1997) proposed a new model known as the Quadratic Almost Ideal Demand System (QUAIDS). This study will estimate the QUAIDS model because this model can differentiate the demand across regions (urban and rural) and, furthermore, can differentiate various income levels in the community. The QUAIDS model proposed by Banks and Lewbel (1997) is an extension of the AIDS model (Deaton and Muellbauer, 1980). Banks and Lewbel (1997) argue that the Engel curve is not linearly related to income. The QUAIDS model is derived from an indirect utility function, as follows:

$$
\ln V=\left\{\left[\frac{\ln x-\ln a(p)}{b(p)}\right]^{-1}+\lambda(p)\right\}^{-1}
$$

where, $\lambda(p)=\sum_{i=1}^{n} \lambda_{i} \ln p_{i}$ is homogeneous of degree zero at price level. Therefore, the utility function in Equation (1) is the PIGLOG model of AIDS, where $\ln a(p)$ and $b(p)$ are the price index, which is formulated as:

$$
\begin{aligned}
\ln a(p)= & \alpha_{0}+\sum_{k} \alpha_{k} \ln \left(p_{k}\right)+ \\
& \frac{1}{2} \sum_{k} \sum_{l} \gamma_{k l} \ln \left(p_{k}\right) \ln \left(p_{l}\right)
\end{aligned}
$$




$$
b(p)=\prod_{i=1}^{n} p_{i}^{\beta_{i}}
$$

where, the price index $a(p)$ must be homogeneous of degree one on price and expenditure, and $b(p)$ must be homogeneous on degree zero. In order to derive the demand function, the utility function in Equation (1) is maximized by fulfilling the three assumptions that must be satisfied, namely: adding-up, homogeneity and, symmetry.

\section{Previous Studies}

Changes in food and commodity prices can have a direct impact on household consumption levels and an indirect impact on household welfare. The first study concerning the impact of commodity price changes on households' welfare was conducted by Deaton (1989) in Thailand. Deaton applied a nonparametric estimation model, known as 'Kernel Density Distribution'. Overall, this study found that higher rice prices will benefit the agricultural sector in rural areas and, furthermore, improve household welfare. However, such welfare depends on the household's land size. Deaton calculated that, among 11,893 households, 2,677 households experienced an improvement in their welfare, while other 3,001 households suffered or experienced a loss. The nonparametric approach was also implemented in the study of Barrett and Dorosh (1996), which investigated the impact of food price changes on farmers' welfare in Madagascar. The study found that most of the farmers in Madagascar do not involved in trading commodities which they are produced, either as buyers or sellers. In this case, the poorer farmers experience a welfare loss.

Minot and Goletti (2000) investigated the impact of liberalization in the rice market in Vietnam. This study employed the Almost Ideal Demand System (AIDS) model to analyze the impact of such liberalization on farmers' incomes and poverty levels. This study found that only $45 \%$ of farmers obtain welfare due to the market's liberalization. Geographically, higher rice prices give more benefits to rural households than urban households. On average, the income loss experienced by the farmers came to about 2\%. Hoang and Glewwe (2011) investigated the impact of an increase in food prices on welfare and poverty rates in Vietnam. They also employed the AIDS model. The results showed that a $20 \%$ price increase in all products, assuming that consumer and producer prices rise proportionally, resulted in an increase in household expenditure by up to $3.4 \%$. If the producer's price is higher than the consumer's price, the agricultural household's welfare will improve.

Another study was conducted by Ivanic and Martin (2008) by applying the agricultural household model's approach for estimating the impact of food price changes on the poverty rate. This study analyzed cross-country studies, namely: Bolivia (2005), Cambodia (2003), Madagascar (2001), Malawi (2004), Nicaragua (2001), Pakistan (1999), Peru (2003), Zambia (1998), and Vietnam (1998 and 2004). In general, a $10 \%$ increase in food prices will create a higher poverty rate. The impact of higher food prices depends on product type, geography, and country. The impact is much larger for urban households than rural households because urban households are the buyers of agricultural commodities.

Attanasio et al. (2013) investigated food price changes in Mexico and Columbia by applying the Quadratic Almost Ideal Demand System (QUAIDS). The study's results indicated that income improvements had an impact on the share of expenditure, especially rice. Overall, the impact of higher prices for food commodities is lower welfare. In other words, the price elasticity of demand is negative. 
In Indonesia, studies of the impact of food commodity price changes on households' welfare were conducted using the standard microeconomic model or standard optimizing model. For example, Ravallion and van der Walle (1991) analyzed the Almost Ideal Demand System (AIDS) model by using data taken from the 1981 SUSENAS. The study's results indicated that trade liberalization in 1981 for various products, including rice, affected the domestic price level. The lower market price level stimulated a higher poverty rate. Ikhsan (2003) conducted a study by applying the net benefit ratio approach proposed by Deaton (1997). Ikhsan's study found that a 10\% increase in the price of rice translated into only $1 \%$ of the poorest households, which is equivalent to two million people.

This study follows a similar approach applied by McCulloch (2008), who used data from the 2004 SUSENAS. McCulloh's study reported that a $10 \%$ increase in price would result in $14 \%$ of households that improve their welfare, but the remaining $86 \%$ experience a drop. This welfare drop is equivalent to $2 \%$ of the higher per capita expenditure for poor households, while non-poor households experience a lower relative income of $0.78 \%$. This paper extends McCulloch's study in several ways. First, McCulloch studied only rice and used the out-of-date data on food consumption patterns from 2004, while this study used three kinds of imported food and data from 2014. Second, McCulloch used consumer prices, while this study used an approach which allows consumer and producer prices to rise at different rates.

\section{METHOD, DATA, AND ANALYSIS}

\section{Data Sources}

Data utilized in this study were elaborated from the National Socio-economic Survey
(SUSENAS), conducted by the Central Bureau of Statistics (Badan Pusat Statistik/BPS). SUSENAS is a nation-wide survey which collects data at the household level. The survey covers information on household characteristics, population, health, education, family planning, housing, as well as income and expenditure. This study used the 2014 data. The 2014 SUSENAS data were selected because the import of consumptions goods in this year was the lowest in the period 2010-2014. This study focused on imported food commodities, namely rice, red onions, and garlic. In the period 2010-2014, there was a tendency for the volume of imported food commodities to keep increasing, and this had reached $12.41 \%$ by 2014 (Badan Pengkajian dan Pengembangan Kebijakan Perdagangan Kementerian Perdagangan, 2015).

There were 285,400 households surveyed in the 2014 SUSENAS. In order to analyze the demand function for food commodities at the household level in Indonesia, the amount of food consumed by each household must be equivalent. In other words, there must be an equivalent amount of food in each bundle of food for consumption. This study applied each household's bundle of food, namely rice and other staple foods, including fish, meat, eggs, red onions, garlic, vegetables, fruit, oil, and so forth. After the data were cleared, 47,554 households were included in this study.

\section{Estimation Strategies}

This study employed the Quadratic Almost Ideal Demand System (QUAIDS) approach in order to investigate the agricultural households' model in Indonesia. Banks and Lewbel (1997) indicated that the Engle curve is not linear, but quadratic. Therefore, the derivation of the demand curve from the indirect utility function can be formulated as: 


$$
\begin{aligned}
& w_{i}=\alpha_{i}+\sum_{j=1}^{n} \gamma_{i j} \ln p_{j}+\left(\beta_{i}+\eta_{i}{ }^{\prime} z\right) \ln \left\{\frac{m}{\overline{m_{0}}(z) a(p)}\right\}+ \\
& \frac{\lambda_{i}}{b(p) c(p, z)}\left[\ln \left\{\frac{m}{\overline{m_{0}}(z) a(p)}\right\}\right]^{2} \\
& c(p, z)=\prod_{j=1}^{n} p_{j}^{n_{j} z^{\prime}} \\
& \sum_{j=1}^{n} \eta_{r j}=0 \text { for } r=1, \ldots, S \\
& \overline{m_{0}}(z)=1+\rho^{\prime} z
\end{aligned}
$$

where index $j$ implies food commodity $(j=1,2,3, \ldots, \mathrm{n}) ; w_{i}$ is the share of the budget for expenditure from household $i ; p_{j}$ is the price level of $j$ commodity, $m$ is the household's total expenditure, and $z$ is the vector of the sociodemographic for household $i$. Bundle of food commodities analyzed in this study are rice, and other staple foods such as fish, meat, eggs, red onions, garlic, vegetables, fruit, oil, and other foods.

There are three types of demand elasticity that can be derived from the QUAIDS model. The three elasticities are as follows:

1. Income elasticity

$\mu_{i}=1+\frac{1}{w_{i}}\left[\beta_{i}+\eta_{i}{ }^{\prime} z+\frac{2 \lambda_{i}}{b(p) c(p, z)} \ln \left\{\frac{m}{\overline{m_{0}}(z) a(p)}\right\}\right]$

2. Uncompensated price elasticity

$\varepsilon_{i j}=-\delta_{i j}+\frac{1}{w_{i}}\left(\gamma_{i j}-\left[\beta_{i}+\eta_{i}{ }^{\prime} z+\frac{2 \lambda_{i}}{b(p) c(p, z)} \ln \left\{\frac{m}{\overline{m_{0}}(z) a(p)}\right\}\right] \times\right.$ $\left.\left(\alpha_{j}+\sum_{l} \gamma_{j l} \ln p_{l}\right)-\frac{\left(\beta_{j}+\eta_{j}{ }^{\prime} z\right) \lambda_{i}}{b(p) c(p, z)}\left[\ln \left\{\frac{m}{\overline{m_{0}}(z) a(p)}\right\}\right]^{2}\right)$

3. Compensated price elasticity

$$
\varepsilon_{i j}^{C}=\varepsilon_{i j}+\mu_{i} w_{j}
$$

To analyze the impact of food price changes on households' welfare, the Compensating Variation (CV) was proposed. This would represent the immediate impact which would be estimated using Equation (8), and the short-term impact using Equation (9). The basic model of Deaton (1989) was followed, which was then improved by using Hoang and Glewwe (2011) by separating producers' and consumers' price levels. The equations will be as follows:

$$
\begin{aligned}
\Delta \ln B_{i}= & w_{i} \Delta \ln p_{c i}-\left(\frac{p_{p i} y_{i}}{X}\right) \Delta \ln p_{p i} \\
\Delta \ln B_{i}^{S T}= & w_{i} \Delta \ln p_{c i}-\left(\frac{p_{p i} y_{i}}{X}\right) \Delta \ln p_{p i}+ \\
& \frac{1}{2} \sum_{j=1}^{n} w_{i} \varepsilon^{c}{ }_{i j} \Delta \ln p_{c i} \Delta \ln p_{c j}
\end{aligned}
$$

where $\Delta B$ is the changes in income which are approached through expenditure, $w_{i}$. This is part of the budget's share for purchasing commodity $i$, but it does not include self-produced commodities. The component of $\left(p_{p i} y_{i} / X\right)$ are the sales of commodity $i ; p_{p i}$ is the producer's price level of good $i, p_{c i}$ is the consumer's price level of $\operatorname{good} i$, and $\varepsilon^{c}{ }_{i j}$ is the elasticity of the compensated price of commodity $i$ for the price level of commodity $j$.

Price changes can be induced through the input price which includes seeds, fertilizer, and the price of labor. The changes in input price will determine the revenue and real profit levels of the farmers. To make it simple, this study would ignore the first part of any price changes. Similar procedures were also adopted in previous studies, including Friedman and Levinsohn, (2002); Hoang and Glewwe, (2011).

Another potential problem from the QUAIDS estimation is the measurement error from self-reports regarding the price levels encountered by each household. Furthermore, the commodity price was not stated precisely in the SUSENAS data, but this price level could be inferred from the value of commodities purchased by the households. The price level was taken from the total value of goods divided by the volume of the commodities. The unit value of the commodity's price was used to 
overcome this condition; which resulted from the division of total value and the number of purchases. This approach was proposed by Cox and Wohlgenant (1986). This model is indicated by the following equation:

$$
v_{i}=\bar{v}_{i}+\varphi_{i} x+\omega_{i} f_{i}+\sum_{m} b_{i} Z_{i m}+e_{i}
$$

where, $\vartheta_{i}$ is the value of good $i^{\prime} s$ classification, which are bought by household. $\bar{\vartheta}_{i}$ which describes the average value of commodity $i$ at the selected commodity (census block), $f_{i}$ is the budget proportion for eating out, $x$ is the per capita expenditure for purchasing food, $z$ is the vector of socio-demographic variables, as indicated by Equation (4), $e_{i}$ is the error term.

The quality adjustment for goods with the price level for each commodity is denoted by $p_{i}$ which is formed by adding up the average value of commodity $i$ at a particular level, and its residual value from Equation (10), $\hat{e}_{i}$.

$$
p_{i}=\bar{v}_{i}+\hat{e}_{i}
$$

The value of $p_{i}$ introduced by Cox and Wohlgenant (1986) are found not to be consistent with the stated hypothesis; that every household will encounter a similar price level. With the value of $\hat{e}_{i}$ that is randomly determined, the value of $p_{i}$ will vary between households at similar markets. To overcome this problem, Niimi (2005); Hoang and Glewwe (2011) proposed to use the average price of each commodities which have been adjusted with quality, $\bar{p}_{i}$ and is formulated as follows:

$$
\bar{p}_{i}=\overline{\bar{v}_{i}+\hat{e}_{i}}
$$

The price level $\bar{p}_{i}$ illustrates that every household in a particular community is assumed to be facing a similar price for a standardized product (the quality effect is ignored). Substituting Equation (12) with Equation (4) will obtain the income elasticity, and the uncompensated and compensated price elasticity. The compensated price elasticity is derived from Equation (7), which is further used to analyze the impact of price increases on welfare. The direct impact is derived from Equation (8) and in the short-term, the impact of price changes is derived from Equation (9). Appendix 1 presents the definition of and summary statistics about the key variables.

\section{RESULT AND DISCUSSION}

\section{Food Consumption in Indonesia}

The SUSENAS data started being collected in 1963, and since then it was conducted annually, but the basis of the data's collection has changed since 2011; when it started being based on a quarterly basis. In 1963, the number of SUSENAS's respondents numbered 16,000 households and continued to increase until it reached 285,400 households in 2014. Data on the expenditure on food consumption were calculated from 215 food items, which were classified into 14 groups, namely: grains, tubers, fish/shrimp/squid/shellfish, meat, eggs and milk, vegetables, nuts, fruit, oils and fats, beverage ingredients, spices, other consumables, food and beverages, tobacco and betel. This study focused on analyzing three types of imported commodities, namely rice, red onions, and garlic.

The analysis of this article aggregates 229 food items into 11 (eleven) groups to be eaten at home and away from home (market), namely: rice, red onions, garlic, other staple foods, fish, meat, eggs, vegetables, fruit, oil, and other foods. The share of total food consumption for each group in this study is as follows: rice (13.56 $\%)$, red onions $(1.24 \%)$, garlic $(0.66 \%)$, other staple foods $(2.06 \%)$, fish $(9.62 \%)$, meat (7.39\%), eggs $(2.94 \%)$, vegetables $(8.68 \%)$, fruit (6.35\%), oil (6.35\%), and other foods (44.55\%). Other foods have the highest share of household food expenditure because this group contains 78 
food items. Rice is still an important food for Indonesian people, especially those living in the countryside or rural areas. The share of households located in rural areas is $15.89 \%$ compared to $12.04 \%$ in urban areas.

The results of the analysis from the SUSENAS data in 2002-2014 showed that rice consumption per capita decreased by 1.31 $\mathrm{kg} /$ year, or $1.39 \% / y e a r . ~ M e a n w h i l e$, red onions' and garlic's consumption increased by 0.24 ounce/capita/year and 0.41 ounce/capita/ year. In the same period, the consumption of local food decreased, for example, the consumption of tapioca/cassava $(421.5 \mathrm{~kg} /$ capita/year $)$, sweet potatoes/yams $(8.67 \mathrm{~kg} /$ capita/year $)$, and taro $(0.005 \mathrm{~kg} /$ capita/year $)$. This condition showed that when the consumption of rice decreased, the largest proportion of household expenditure went to purchase these commodities. This implied that the price of rice would lead to a decrease in the households' welfare if they are net consumers of rice and an increase in welfare if they are net producers of rice, and vice versa if there is a decrease in rice prices. The results of some previous studies in
Indonesia such as those by Ravallion and van der Walle (1991), Ikhsan (2003), and McCulloch (2008) indicated that a rise in rice prices tends to reduce people's welfare. Therefore, the rice price policy must be controlled by the government, so that price fluctuations can be controlled, and, furthermore, the well-being of the individual and community will not change dramatically.

Based on the regional classifications, rural areas, other than those in Java and Bali, as well as the eastern region, are the regions which have a larger expenditure on food than the other regions (urban, Java and Bali, as well as the western region). The total expenditure on rice for food consumption in rural areas is 3.85\% higher than it is in urban areas. Java and Bali accounted for $0.08 \%$ lower than the regions outside Java and Bali. Meanwhile, the western region is $0.29 \%$ higher than the eastern region. These differences suggest that policies related to rice do not apply throughout Indonesia. Therefore, the Indonesian government should pay a great deal of attention to the characteristics of the regions.

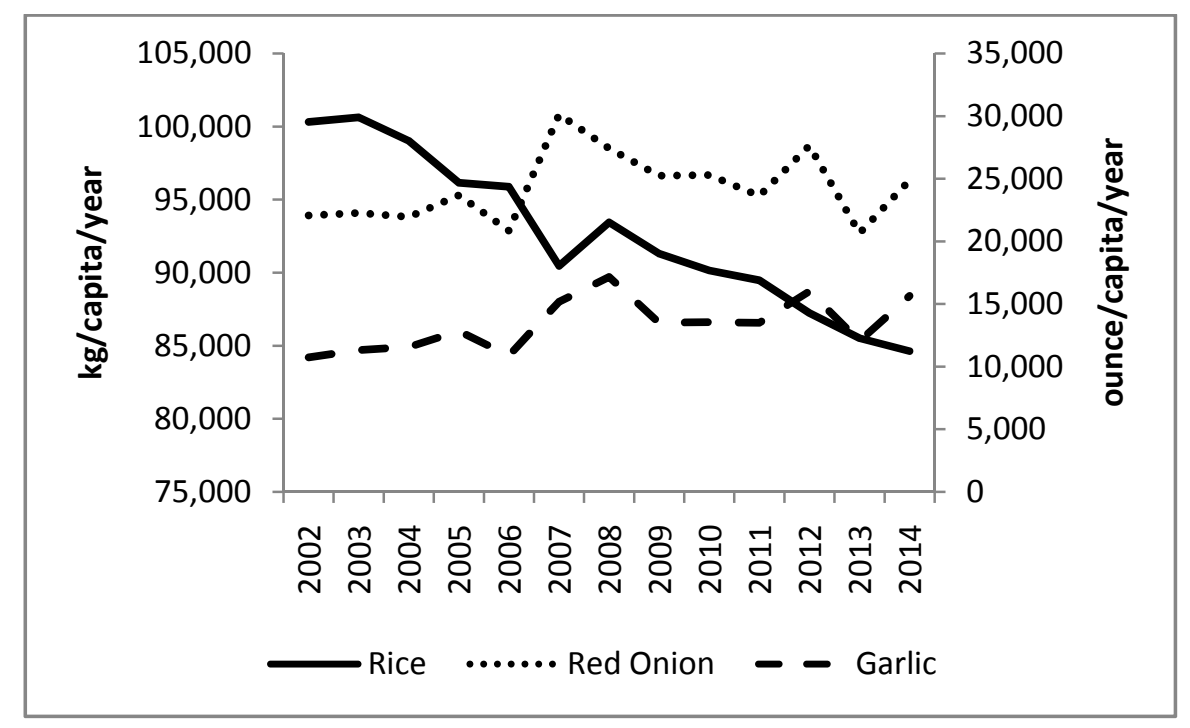

Figure 1. Consumption of Rice (kg/capita/year), Red Onion, and Garlic (ounce/capita/year) Source: SUSENAS Data (2002-2014) 
Based on income groups, the subgroups at the lowest percentile level have a high proportion of food consumption expenditure, and the highest percentile have a low proportion with a margin of $4.11 \%$. This condition is inversely related to the proportion of expenditure on food-away-from-home to total food consumption, where households with higher incomes have greater expenditure, by approximately $2.21 \%$, than the lowest income groups. In regard to the areas, it is found that $79.11 \%$ of those living in urban areas belong to the highest income group. Living in urban areas, households have limited rice fields, or even do not have land to produce their own food.

Based on the working groups, those who work in the agricultural sector will have a greater proportion of their spending power for buying rice than those who work in nonagricultural sectors. The difference between the two groups is $3.39 \%$. Those who work in the agricultural sector require more energy, which they generate from consuming carbohydrates than those who work in non-agricultural sectors. A source of carbohydrates, which is easily processed and can be quickly accessed, is rice. As a result, the rice consumption for those who work in the agricultural sector is greater than for those in non-agricultural sectors.

\section{Food Price Changes in Indonesia}

Food commodity prices in Indonesia have continuously increased, by an average of 5.08\% per year (2011-2014). In this period, the largest commodity price increase is for cayenne peppers (12.92\%/year) and beef (12.31\%/year). The price increase is mainly affected by several factors, including the world and Asian financial crises, world food prices, import tariffs, higher input prices, and crop failures (Abbott, 2009; Mitchell, 2008). On the other hand, persistent price increases will have an impact on the proportion of household income for consuming food. This is consistent with the study of Ivanic and Martin (2008) who investigated nine low-income countries. They found that an increase in staple food prices in the short term will increase the poverty level.

On the other hand, the price increase will improve farmers' welfare through the higher revenue they get from the sale of food products. This situation can occur if the farmer is a net seller who is able to produce more than the amount his/her family consumes. Results of the study conducted by Dimova (2015) showed that a rise in food prices will give an opportunity for opening new jobs in the agricultural sector.

Price changes can also be derived from the value of the Consumer Price Index (CPI) and the Producer/Wholesale Price Index (PPI). CPI and PPI in Indonesia tend to increase every year by $11.65 \%$ and $14.22 \%$ respectively (1971-2015). The CPI and PPI increased very significantly during the economic crisis in Indonesia in $1997 / 1998$, in which the CPI rose by $58.39 \%$ and the PPI by $102.10 \%$. The comparison between the CPI and the PPI shows that before 2010 the CPI value was always above the PPI, but after this year, the PPI was above the CPI. This condition indicates that the average price changes received by the domestic producers of goods are greater than the average price changes paid by consumers for the group of goods consumed. In other words, inflation at the producer level was higher than that at the consumer level. 
Table 1. Consumer Price Indices/CPI $(2007=100)$ and Producer Price Indices/PPI $(2010=100)$ in Indonesia, 2010-2013.

\begin{tabular}{rrrrrr}
\hline \multirow{2}{*}{2010} & & Quarter I & Quarter II & Quarter III & Quarter IV \\
\hline \multirow{2}{*}{2011} & PPI & 97.21 & 98.24 & 100.66 & 103.88 \\
& CPI & 118.19 & 119.86 & 123.21 & 125.17 \\
& PPI & 108.32 & 109.32 & 111.06 & 112.09 \\
& CPI & 126.05 & 126.50 & 128.89 & 129.91 \\
& PPI & 114.44 & 113.90 & 114.09 & 114.52 \\
& CPI & 131.05 & 132.23 & 134.45 & 135.49 \\
& PPI & 116.90 & 115.94 & 119.34 & 121.91 \\
& CPI & 138.78 & 140.03 & 145.75 & 146.84 \\
\hline
\end{tabular}

Source: BPS (2018).

The PPI and CPI show a pattern in prices for the early part of the year and the end of the year when those indices tend to be higher than they are in the early part of the year. Table 1 also shows that the inflation rate for food commodities increases at the beginning and end of the year. The inflation caused by food production in the country increases at the beginning of the year and tends to decrease at the end of the year because of the rainy season (Case et al., 2007).

\section{Income and Price Elasticities}

Based on the analysis, the people living in urban areas tend to have a smaller proportion of expenditure on rice, red onions, garlic, other staple foods, fish, meat, eggs, vegetables, and oil than on fruit and other food. This shows that the consumption pattern of the urban areas tends to consume other food more. The consumption pattern shows that the urban population in Indonesia has a worse pattern of food management than those who live in rural areas. Based on the division of the regions (western region and eastern region of Indonesia), people living in the western region are likely to have a higher proportion of spending on rice than those living in the eastern region. This is because the main food products in the eastern region are more diverse than those in the western region, such as sago, cassava, sweet potatoes, and corn. The results of studies conducted by Rachman (2001) and Sayekti (2008) indicated that household food in eastern Indonesia (non-historically a rice eating area) is more varied than that in western Indonesia (historically a rice eating area).

Based on income groups, people with middle and lower incomes have a tendency to increase their proportion of expenditure on food compared to those in the high-income group. This suggests that food policies should not only pay attention to the condition of the region, but also the income distribution. Price policies are not based on pro-poor and those vulnerable to poverty. This leads to a high number of poor people, due to rising prices. The study conducted by Warr and Yusuf (2014) revealed that rising prices lead to a rise in poverty, especially in rural areas.

The demographic characteristics indicate that the impact of the proportion of expenditure on consumption is different among different groups of goods. The marital status of the household's head, his/her education level, and the number of 
household members working all have a negative impact on rice. The proportion of expenditure on the consumption of red onions has a negative impact on the sex of household head, the number of members of a household under and over 5 years old, and employment status. Meanwhile, for garlic, only education has a positive impact on the proportion of expenditure on this food item. The implication is that the difference in demographic characteristics leads to differences in consumers' behavior. This condition indicates that food policies should take the demographic characteristics of the population into consideration.

The results from the QUAIDS model shows that there is a negative correlation between the number of household members and the demand for some food items, such as red onions and garlic. This indicates that the items mentioned above are private goods for households in Indonesia, especially those in the lower income group. This phenomenon is called the DeatonPaxson paradox proposed by Deaton and Paxson (1998). The study conducted by Deaton and Paxson (1998) in several countries: the United States, the United Kingdom, France, Taiwan, Thailand, Pakistan, and South Africa, indicated the negative correlation between the number of family members and the demand for food. This is because food consumed by people cannot be substituted with cheaper public goods, particularly in low-income countries. This result is different for rice; a household with more infants and adults consumes more rice. This implies that a household with more household members spends a higher proportion on various at-home foods such as rice.

Regarding the role of the education level of the household's head, there is a clear and negative impact on the consumption of rice and a positive impact on the consumption of red onions and garlic. This means that households with a better-educated household head tend to consume fewer carbohydrates derived from rice, and consume more protein-rich foods such as fish, meat, and eggs, and consume more vegetables and fruit than households with a less well-educated household head. This means the better education of the household head has a positive impact for a better quality of life for the household's members. Female-headed households consume more food-away-from-home and rice than male-headed households. This condition occurs because female-headed households spend more time outside the home earning a living for their families. The quadratic expenditure term shows it is statistically significant at $1 \%$ for all commodities. This means that the null hypothesis of expenditure linearity is rejected. The QUAIDS model in this study is a good model to predict the demand function of food in Indonesia.

The results show that the income elasticity for all the groups of commodities is positive, suggesting that an increase in the household's income will increase the consumption demand for all types of food. All groups of commodities are normal goods, meaning that an increase in income will lead to a rise in the demand for food. The income elasticity of demand for all commodities is less than one, meaning that all the groups of commodities are considered to be a necessity. The same condition occurs in urban areas and rural areas. Income elasticity for all the groups of commodities (except eggs) in rural areas is greater than in urban areas. It indicates that an increase in household income will be allocated for purchasing food products in rural areas to a greater extent than in urban areas. This is in line with the results of previous analyses showing the trend of increasing consumption per capita of the population of Indonesia. Thus, the stability of prices will have a positive impact on the welfare of the people, especially those living in rural areas. 
Table 2. The result from the QUAIDS ${ }^{1}$ (Dependent variable: budget share for expenditure).

\begin{tabular}{|c|c|c|c|c|c|c|}
\hline & \multicolumn{2}{|c|}{ Rice } & \multicolumn{2}{|c|}{ Red Onion } & \multicolumn{2}{|c|}{ Garlic } \\
\hline & coef & stdv & coef & stdv & coef & stdv \\
\hline \multicolumn{7}{|l|}{ Ln Price } \\
\hline Rice & $0.056^{* * *}$ & $(0.003)$ & $0.002 * * *$ & $(0.000)$ & $-0.003 * * *$ & $(0.000)$ \\
\hline Red onions & 0.002 & $(0.002)$ & $0.001 * * *$ & $(0.000)$ & $0.001 * * *$ & $(0.000)$ \\
\hline Garlic & $-0.003 *$ & $(0.002)$ & $0.001 * * *$ & $(0.000)$ & $0.003 * * *$ & $(0.000)$ \\
\hline Other staple foods & $-0.025 * * *$ & $(0.002)$ & 0.000 & $(0.000)$ & $0.002 * * *$ & $(0.000)$ \\
\hline Fish & $0.004 * *$ & $(0.002)$ & $-0.001 * * *$ & $(0.000)$ & $-0.003 * * *$ & $(0.000)$ \\
\hline Meat & $-0.005 * * *$ & $(0.002)$ & $-0.002 * * *$ & $(0.000)$ & $-0.001 * * *$ & $(0.000)$ \\
\hline Eggs & 0.002 & $(0.002)$ & -0.000 & $(0.000)$ & $0.001 * * *$ & $(0.000)$ \\
\hline Vegetables & $-0.013 * * *$ & $(0.002)$ & $0.001 * * *$ & $(0.000)$ & $-0.002 * * *$ & $(0.000)$ \\
\hline Fruits & 0.000 & $(0.002)$ & 0.000 & $(0.000)$ & $0.001 * * *$ & $(0.000)$ \\
\hline Oil & 0.004 & $(0.003)$ & $-0.002 * * *$ & $(0.000)$ & $0.002 * * *$ & $(0.000)$ \\
\hline Other foods & $-0.022 * * *$ & $(0.001)$ & 0.000 & $(0.000)$ & 0.000 & $(0.000)$ \\
\hline \multicolumn{7}{|l|}{ Ln Expenditure } \\
\hline Expenditure & $-0.309 * * *$ & $(0.008)$ & $-0.017 * * *$ & $(0.001)$ & $-0.017 * * *$ & $(0.001)$ \\
\hline Expenditure Square & $0.012 * * *$ & $(0.000)$ & $0.001 * * *$ & $(0.000)$ & $0.001^{* * *}$ & $(0.000)$ \\
\hline \multicolumn{7}{|c|}{ Demographic characteristics } \\
\hline Age & $0.000 * * *$ & $(0.000)$ & $0.000 * * *$ & $(0.000)$ & $0.000 * * *$ & $(0.000)$ \\
\hline Sex & $0.005 * * *$ & $(0.001)$ & $-0.001 * * *$ & $(0.000)$ & $-0.000 * * *$ & $(0.000)$ \\
\hline Married & $-0.005^{*}$ & $(0.003)$ & 0.000 & $(0.000)$ & $-0.000^{*}$ & $(0.000)$ \\
\hline Education & $-0.003^{* * *}$ & $(0.000)$ & $0.000^{* * *}$ & $(0.000)$ & $0.000^{* * *}$ & $(0.000)$ \\
\hline HHsize $\leq 5$ & $0.002 * * *$ & $(0.000)$ & $-0.001 * * *$ & $(0.000)$ & $-0.000 * * *$ & $(0.000)$ \\
\hline HHsize $>5$ & $0.015^{* * *}$ & $(0.000)$ & $-0.000 * * *$ & $(0.000)$ & $-0.000 * * *$ & $(0.000)$ \\
\hline HHsize work & $-0.001 * * *$ & $(0.000)$ & 0.000 & $(0.000)$ & $-0.000 * * *$ & $(0.000)$ \\
\hline Work & $0.004 * * *$ & $(0.001)$ & -0.000 & $(0.000)$ & -0.000 & $(0.000)$ \\
\hline Constanta & $1.982 * * *$ & $(0.045)$ & $0.130 * * *$ & $(0.006)$ & $0.120 * * *$ & $(0.004)$ \\
\hline
\end{tabular}

Note: $\mathrm{N}=47,554 ; * * * \mathrm{p}<0.01, * * \mathrm{p}<0.05, * \mathrm{p}<0.1$

Source: Secondary Data, analyzed

Table 3 also shows the analysis of the price elasticity of own-price for some food commodities in Indonesia, both the Marshallian (uncompensated) and Hicksian (compensated) price elasticity. The analysis shows that all the groups of commodities have a negative value, meaning that price increases in any type of food will reduce the demand for

\footnotetext{
${ }^{1}$ The QUAIDS models were estimated using the nonlinear Seemingly Unrelated Regression (SUR).
}

it. The type of rice has a positive impact in rural areas for the compensated price elasticity (Hicksian). It means that a rise in rice prices will increase the demand for rice. Household characteristics in rural areas are different from urban areas. Rural households have a role as consumers and producers, while households in urban areas are consumers. This condition causes the positive value of elasticity for rice in rural areas. 
Table 3. Expenditure and Own-Price Elasticities

\begin{tabular}{|c|c|c|c|c|c|c|c|c|c|}
\hline & \multicolumn{3}{|c|}{ All } & \multicolumn{3}{|c|}{ Rural } & \multicolumn{3}{|c|}{ Urban } \\
\hline & \multirow{2}{*}{ Exp } & \multicolumn{2}{|c|}{ Own Price } & \multirow{2}{*}{ Exp } & \multicolumn{2}{|c|}{ Own Price } & \multirow{2}{*}{ Exp } & \multicolumn{2}{|c|}{ Own Price } \\
\hline & & $\mathbf{M}$ & $\mathbf{H}$ & & $\mathbf{M}$ & $\mathbf{H}$ & & $\mathbf{M}$ & $\mathbf{H}$ \\
\hline Rice & 0.853 & -0.814 & 0.213 & 0.862 & -0.743 & 0.834 & 0.847 & -0.840 & -0.017 \\
\hline Red onions & 0.864 & -0.972 & -0.909 & 0.862 & -0.976 & -0.868 & 0.860 & -0.967 & -0.914 \\
\hline Garlic & 0.849 & -0.951 & -0.897 & 0.852 & -0.958 & -0.865 & 0.846 & -0.946 & -0.902 \\
\hline Other staple foods & 0.853 & -0.964 & -0.833 & 0.855 & -0.967 & -0.740 & 0.850 & -0.945 & -0.840 \\
\hline Fish & 0.721 & -0.865 & -0.981 & 0.776 & -0.919 & -1.102 & 0.668 & -0.787 & -0.864 \\
\hline Meat & 0.927 & -0.59 & -0.492 & 0.985 & -0.289 & -0.219 & 0.985 & -0.454 & -0.389 \\
\hline Eggs & 0.889 & -0.971 & -0.888 & 0.876 & -0.976 & -0.846 & 0.882 & -0.946 & -0.865 \\
\hline Vegetables & 0.865 & -0.952 & -0.554 & 0.860 & -0.908 & -0.247 & 0.859 & -0.956 & -0.586 \\
\hline Fruits & 0.671 & -1.464 & -1.502 & 0.630 & -2.533 & -2.545 & 0.072 & -2.331 & -2.332 \\
\hline Oil & 0.855 & -0.963 & -0.769 & 0.856 & -0.941 & -0.612 & 0.852 & -0.972 & -0.810 \\
\hline Other foods & 0.769 & -1.294 & -2.188 & 0.817 & -1.387 & -3.386 & 0.728 & -1.272 & -1.896 \\
\hline
\end{tabular}

Notes: Exp=expenditure; $\mathrm{M}=$ Marshallian; $\mathrm{H}=$ Hicksian

Source: Secondary Data, analyzed

Table 4. Cross-Price Elasticity (Marshallian and Hicksian)

\begin{tabular}{|c|c|c|c|c|c|c|c|c|c|c|c|}
\hline & Rice & $\begin{array}{c}\text { Red } \\
\text { onions }\end{array}$ & Garlic & $\begin{array}{l}\text { Other } \\
\text { staple } \\
\text { foods }\end{array}$ & Fish & Meat & Eggs & $\begin{array}{l}\text { Vege- } \\
\text { tables }\end{array}$ & Fruit & Oil & $\begin{array}{l}\text { Other } \\
\text { foods }\end{array}$ \\
\hline \multicolumn{12}{|l|}{ Uncompensated } \\
\hline Rice & & 0.009 & 0.005 & -0.002 & -0.029 & 0.007 & 0.011 & 0.039 & -0.010 & 0.029 & -0.207 \\
\hline Red onions & 0.160 & & 0.018 & 0.020 & -0.046 & -0.017 & 0.008 & 0.065 & -0.009 & -0.002 & -0.183 \\
\hline Garlic & 0.080 & 0.020 & & 0.040 & -0.076 & -0.002 & 0.016 & 0.008 & 0.008 & 0.061 & -0.176 \\
\hline Other staple foods & -0.043 & 0.008 & 0.016 & & -0.053 & 0.029 & 0.072 & 0.096 & -0.048 & 0.068 & -0.156 \\
\hline Fish & 0.151 & 0.016 & 0.028 & 0.047 & & 0.170 & -0.019 & -0.062 & -0.039 & 0.055 & -0.467 \\
\hline Meat & -0.129 & -0.024 & -0.011 & 0.019 & -0.230 & & -0.029 & -0.009 & -0.067 & -0.040 & 0.031 \\
\hline Eggs & 0.144 & 0.006 & 0.012 & 0.123 & 0.024 & -0.016 & & -0.023 & -0.024 & -0.028 & -0.209 \\
\hline Vegetables & 0.096 & 0.010 & 0.002 & 0.034 & 0.014 & 0.015 & -0.006 & & -0.013 & 0.020 & -0.187 \\
\hline Fruits & 0.454 & 0.025 & 0.004 & 0.165 & -0.165 & 0.167 & 0.056 & 0.195 & & 0.131 & -0.388 \\
\hline Oil & 0.150 & -0.001 & 0.018 & 0.048 & -0.047 & -0.001 & -0.012 & 0.041 & -0.022 & & -0.176 \\
\hline Other foods & 0.225 & 0.012 & 0.011 & 0.026 & -0.077 & 0.019 & 0.017 & 0.081 & -0.007 & 0.038 & \\
\hline \multicolumn{12}{|l|}{ Compensated } \\
\hline Rice & & 0.072 & 0.060 & 0.129 & -0.166 & 0.097 & 0.090 & 0.432 & -0.059 & 0.222 & -1.199 \\
\hline Red onions & 1.200 & & 0.074 & 0.152 & -0.185 & 0.074 & 0.088 & 0.462 & -0.058 & 0.194 & -1.188 \\
\hline Garlic & 1.102 & 0.082 & & 0.171 & -0.213 & 0.088 & 0.096 & 0.399 & -0.040 & 0.253 & -1.163 \\
\hline Other staple foods & 0.985 & 0.070 & 0.071 & & -0.191 & 0.119 & 0.152 & 0.488 & -0.096 & 0.261 & -1.149 \\
\hline Fish & 1.020 & 0.069 & 0.074 & 0.158 & & 0.246 & 0.048 & 0.270 & -0.080 & 0.218 & -1.306 \\
\hline Meat & 0.986 & 0.043 & 0.048 & 0.161 & -0.379 & & 0.058 & 0.417 & -0.119 & 0.170 & -1.047 \\
\hline Eggs & 1.214 & 0.071 & 0.069 & 0.259 & -0.119 & 0.078 & & 0.386 & -0.075 & 0.173 & -1.242 \\
\hline Vegetables & 1.138 & 0.073 & 0.057 & 0.167 & -0.125 & 0.106 & 0.075 & & -0.062 & 0.215 & -1.193 \\
\hline Fruits & 1.262 & 0.074 & 0.047 & 0.268 & -0.272 & 0.238 & 0.118 & 0.504 & & 0.283 & -1.168 \\
\hline Oil & 1.180 & 0.061 & 0.072 & 0.180 & -0.184 & 0.089 & 0.067 & 0.434 & -0.070 & & -1.171 \\
\hline Other foods & 1.151 & 0.068 & 0.060 & 0.144 & -0.201 & 0.101 & 0.089 & 0.435 & -0.050 & 0.212 & \\
\hline
\end{tabular}

Source: Secondary Data, analyzed 
The analysis of price elasticity of other goods (cross-price) shows that an increase in rice prices will reduce the demand for other staple foods and meat, and increase the demand for red onions, garlic, fish, eggs, vegetables, fruits, oil, and other foods. The negative elasticity of crossprice suggests that rice is a complementary good, while positive elasticity is in the substitute goods. It also occurs for red onions and garlic. This suggests that an increase in the price of rice, red onions, and garlic tends to increase the demand for other types of food (compensated price elasticity).

\section{Impact on Welfare of Rising Food Prices in Indonesia}

Six scenarios were used to analyze the impact of rising food prices (rice, red onions, and garlic) in Indonesia. The first scenario was that food prices increased at the consumers' level by $15 \%$, while the rate of producers' prices increased by $10 \%$. The second scenario was the same as the first scenario except that the producers' prices rise by $15 \%$. The third scenario was the same as the first scenario except the producers' prices rise by $5 \%$. The fourth, fifth and sixth scenarios were that the consumers' price level rose by $30 \%$, while the rate of producers' prices increased by $25 \%$, $30 \%$, and $15 \%$ respectively. The scenario in which the producers' and consumers' prices increased by the same amount was also assumed by Deaton (1989), Ivanic and Martin (2008), and Hoang and Glewwe (2011). This scenario indicates no substitution effect in consumer demand.

In general, the welfare impact of price increases in the immediate and short-term on households in Indonesia is negative (Table 5 and Table 6). In addition, the short-term impact is greater than the immediate impact. The differences in the impacts are in the availability of resources (capital, land, labor, information) for the households. Moreover, the choice of consumption, their sources of income, and the location of their residence are the driving factors behind rising food prices that differ from each other among households. Levinsohn, Berry, and Friedman (2003) argue that differences between the impact of prices and household welfare levels are due to regional differences, product differences, and household characteristics. Households without the resources to cope with the rise in prices will continue to decrease their welfare level, while households with resources are going to use those resources to cope with the rising food prices.

In regard to the immediate impact, rural areas experience a smaller impact on welfare than urban areas. This situation is the same for the short-term impact. Urban households are characterized by their active consumption and rarely producing anything. If there is an increase in food prices, the immediate impact -show greater decline in welfare. Rural households are households with two functions in an economy, namely as consumers and producers (Singh et al., 1986). Therefore, the immediate impact of the price increase would be smaller on this group than on other groups. Rural households will have a negative impact on rising prices as consumers, but as producers, they gain more benefits. In the long term, the price increase will have an impact on the rising prices of production inputs, so that the benefits of rising food prices as a producer will be smaller.

The analysis also showed that the immediate impact of rising food prices on farmer welfare in Java and Bali is greater than for those who live outside Java and Bali. However, in the shortterm, households outside Java and Bali experience a larger decline in their well-being than those in Java and Bali. This results from the differences in the flow of goods, services, and information. The flow of goods and services in 
Java and Bali is quick, leading to rising food prices. Consequently, it will dramatically reduce household wealth as the immediate impact, compared to other regions. Moreover, a pro-Java and Bali food price policy, as well as the impact of the price increase, will only occur as an immediate impact. Results of research conducted by Garcia (2000) show that during the period 1987-1995 (intervention regime) policies for the primary sector and manufacturing were concentrated on Java, especially in urban areas, which caused inequalities in income and prices between the regions in Indonesia.

Table 5. Household Welfare Change due to Food Price Increases at Immediate Effect (\%)

\begin{tabular}{|c|c|c|c|c|c|c|}
\hline \multirow{2}{*}{$\begin{array}{l}\text { + Consumer price } \\
\text { + Producer price }\end{array}$} & \multicolumn{3}{|c|}{$15 \%$} & \multicolumn{3}{|c|}{$30 \%$} \\
\hline & $10 \%$ & $15 \%$ & $5 \%$ & $25 \%$ & $30 \%$ & $20 \%$ \\
\hline All (sample) & -5.274 & -1.720 & -8.993 & -6.365 & -3.229 & -9.628 \\
\hline Urban & -6.071 & -2.682 & -9.618 & -8.025 & -5.035 & -11.137 \\
\hline Rural & -4.058 & -0.252 & -8.040 & -3.831 & -0.474 & -7.326 \\
\hline Java and Bali & -4.931 & -1.166 & -8.872 & -5.511 & -2.190 & -8.969 \\
\hline Outside Java and Bali & -5.558 & -2.180 & -9.094 & -7.073 & -4.092 & -10.175 \\
\hline Western Region & -5.365 & -1.809 & -9.087 & -6.534 & -3.397 & -9.800 \\
\hline Eastern Region & -4.611 & -1.075 & -8.311 & -5.137 & -2.017 & -8.384 \\
\hline Percentile 1 & -3.097 & 1.116 & -7.506 & -1.623 & 2.094 & -5.492 \\
\hline Percentile 2 & -3.740 & 0.364 & -8.035 & -2.937 & 0.684 & -6.706 \\
\hline Percentile 3 & -4.273 & -0.337 & -8.392 & -4.105 & -0.632 & -7.719 \\
\hline Percentile 4 & -5.122 & -1.499 & -8.913 & -6.011 & -2.814 & -9.337 \\
\hline Percentile 5 & -6.370 & -3.215 & -9.672 & -8.819 & -6.035 & -11.717 \\
\hline Working in agricultural sector & -3.586 & 0.336 & -7.690 & -2.830 & 0.630 & -6.432 \\
\hline Working outside agricultural sector & -5.848 & -2.419 & -9.436 & -7.567 & -4.542 & -10.715 \\
\hline
\end{tabular}

Source: Secondary Data, analyzed

Table 6. Household Welfare Change due to Food Price Increases at Short-Term Effect (\%)

\begin{tabular}{|c|c|c|c|c|c|c|}
\hline \multirow{2}{*}{$\begin{array}{l}\text { + Consumer price } \\
+ \text { Producer price }\end{array}$} & \multicolumn{3}{|c|}{$15 \%$} & \multicolumn{3}{|c|}{$30 \%$} \\
\hline & $10 \%$ & $15 \%$ & $5 \%$ & $25 \%$ & $30 \%$ & $20 \%$ \\
\hline All (sample) & -7.629 & -5.174 & -10.198 & -16.715 & -15.399 & -18.085 \\
\hline Urban & -8.507 & -6.254 & -10.865 & -18.732 & -17.624 & -19.885 \\
\hline Rural & -6.289 & -3.525 & -9.182 & -13.638 & -12.005 & -15.339 \\
\hline Java and Bali & -7.307 & -4.650 & -10.088 & -15.951 & -14.464 & -17.499 \\
\hline Outside Java and Bali & -7.896 & -5.609 & -10.291 & -17.350 & -16.176 & -18.572 \\
\hline Western Region & -7.738 & -5.289 & -10.302 & -16.963 & -15.658 & -18.321 \\
\hline Eastern Region & -6.838 & -4.340 & -9.451 & -14.925 & -13.526 & -16.382 \\
\hline Percentile 1 & -5.313 & -2.133 & -8.641 & -11.361 & -9.356 & -13.449 \\
\hline Percentile2 & -6.030 & -2.994 & -9.207 & -13.004 & -11.152 & -14.931 \\
\hline Percentile 3 & -6.595 & -3.742 & -9.581 & -14.310 & -12.631 & -16.058 \\
\hline Percentile 4 & -7.476 & -4.952 & -10.118 & -16.358 & -14.980 & -17.792 \\
\hline Percentile 5 & -8.770 & -6.733 & -10.900 & -19.364 & -18.434 & -20.333 \\
\hline Working in agricultural sector & -5.777 & -2.877 & -8.812 & -12.459 & -10.692 & -14.299 \\
\hline Working outside agricultural sector & -8.259 & -5.955 & -10.670 & -18.163 & -17.001 & -19.373 \\
\hline
\end{tabular}

Source: Secondary Data, analyzed 
Based on the groups of income, the immediate impact of the price increase has the same trend in the short-term, that the low-income group experiences a lower impact than the middle and high-income groups. The increasing prices will make households with low incomes reallocate their budgets to buy food quickly. Meanwhile, those with medium and high incomes will tend to be slower to respond to the price increases. Dimova (2015) found that the middle to high-income groups, and those who do not work in the agricultural sector, will experience a greater impact of price increases than the low-income group (poorest population).

The same phenomenon also occurs for the type of work, in which households working in the agricultural sector will suffer a smaller impact than those who work outside the agricultural sectors for the immediate and short-term impacts. Agricultural households are highly dependent on the availability and price of facilities and infrastructure for production (seeds, fertilizer, pharmaceuticals, agricultural equipment) because their main livelihood is their farming activities. The rising food prices will result in rising prices for items of agricultural infrastructure in the short-term. This will then affect the productivity of the agricultural sector. For the immediate impact, the scenario which has the same rate between both consumer and producer prices gives a positive impact on households working in the agricultural sector. This implies these households will benefit from price increases. However, the impact of price increases is negative in the short-term. Datt and Ravallion (1998) showed that the decline in agricultural productivity would increase the number of poor in India. Another factor is when it is possible to earn an income, in which those who work outside the agricultural sector are likely to receive an income every month, while agricultural households depend on the growing season. This lessens the immediate impact of rising food prices on the welfare of households working in agriculture more than the short-term impact does.

\section{CONCLUSION}

This study aims to analyze the demand function of households in Indonesia by using the Quadratic Almost Ideal Demand System (QUAIDS) to identify the impact of rising food prices on the welfare levels of Indonesian people, especially those living in rural areas. Data were obtained from the 2014 National Socio-economic Survey (SUSENAS). The results showed that the consumption of various types of food, namely rice, red onions, garlic, other staple foods, fish, meat, eggs, vegetables, fruit, oils, and other food was affected by income and price, and demographic and geographic factors.

In general, the analysis showed that the income elasticity of all the groups of commodities is positive. This means that all the groups' commodities are normal goods. Rice is still primarily consumed by Indonesian people, but it has a negative trend. Recently, Indonesian society has tended to consume food made from refined flour, such as instant noodles, boiled noodles, and others, and consume more fruit and vegetables. It can be seen that the income elasticity of fruit and vegetables will be positive. Despite changes in the pattern of household consumption for staple foods (rice and other staple foods), this does not mean that price policies (price market mechanisms) are not needed.

Price stabilization policies by the government, such as importing rice, red onions and garlic are still needed because a large number of Indonesia's population still consume rice and red onions and garlic, items that are almost always found in all dishes. Based on the analysis, price increases in red onions and garlic tend to 
increase the demand for other food items. In addition, the results of the analysis which distinguished the various income groups show that the largest decrease in the consumption of rice, in the case of rising prices, is indicated by those in the middle and upper-income groups. In addition to pricing policies, policies that can increase revenue are also needed to boost the demand for commodities like side-dishes (fish and meat) vegetables and fruit, which will create jobs in the agricultural sector.

The impact of price increases, as the immediate impact, is lower than the short-term impact and depends on demographic, geographic, and socio-economic conditions. If the rise in producer prices is faster than that in consumer prices, the welfare of the consumers will tend to decrease. The immediate and shortterm impacts show that the group of households living in villages outside Java and Bali, and in the eastern region of Indonesia, who are in the low-income group, and those working in the agricultural sector experience a smaller impact from the rise in food prices on their levels of prosperity than the other groups. This is due to the differences in the availability of resources (capital, land, labor, and information) for each household group.

The government policy on food should take demographic and geographic elements into consideration. The analysis showed that rural areas are more responsive to price changes than the urban areas. Meanwhile, based on whether the household is in Java and Bali or outside these two regions, the analysis showed that those who live in areas outside Java and Bali experienced a greater decline in demand than those who live in Java and Bali for rice. This is because the rice production centers are mainly located in Java and Bali, while the production centers for other staple foods are located outside Java and Bali.

\section{LIMITATION AND SUGGESTION}

This study has two limitations in econometric issues which should be explored by future research. First, is the problem of endogeneity. Lecocq and Robin (2015) stated that the QUAIDS model might have an endogeneity problem in the household expenditure variable. Wooldridge (2012) suggests three ways to overcome the problem: (1) Ignoring the problem but there will be bias and inconsistency in the estimation. (2) Trying to find and use other variables to replace variables that indicate endogeneity problems. (3) Assuming that the omitted variables do not change over time. The endogeneity problems can be overcome by using several methods, including the first difference, fixed effect, and instrumental variables.

Second, zero expenditure. The value of the dependent variable, $w_{i}$ in the QUAIDS model is a non-negative value. This condition cannot be avoided if we use consumption data at the micro level, because there are households that did not buy some of the commodities during the survey period (for example: SUSENAS only asks about purchases in the past week). This condition is also caused by the lifestyle of the household (for example: vegetarian). If the households with zero expenditure are eliminated, it will cause a bias in the estimation results or what is often known as the selection problem (Moeis, 2003). To overcome this problem, commodity grouping is carried out. If the result still contains a zero value for expenditure, the Inverse Mills Ratio (IMR) variable is added as an independent variable. The IMR variable is obtained by performing a two-step estimation from the Heckman test.

\section{REFERENCES}

Abbott, P. (2009). Development dimensions of high food prices. OECD Food, Agriculture 
and Fisheries Working Papers, No. 18. OECD Publishing.

Attanasio, O., Di Maro, V., Lechene, V., \& Phillips, D. (2013). Welfare consequences of food prices increases: Evidence from rural Mexico. Journal of Development Economics, 104, 136-151.

Badan Pengkajian dan Pengembangan Kebijakan Perdagangan Kementerian Perdagangan. (2015). Pra-Outlook Ekonomi Pertanian 2016. Retrieved August 24, 2016, from http://www.perhepi.org/wpcontent/uploads/2015/09/Bahan-OutlookEkonomi-Pertanian-Indonesia-2015_as-of23-Sept-152.pdf

Bank Indonesia. (2016). Tingkat inflasi di Indonesia 2003-2015 [Indonesian inflation rate 2003-2015]. Retrieved August 24, 2016, from http://www.bi.go.id/id/moneter/ inflasi/data/Default.aspx

Banks, J., Blundell, R., \& Lewbel, A. (1997). Quadratic Engel curves and consumer demand. Review of Economics and Statistics, 79(4), 527-539.

Barrett, C. B., \& Dorosh, P. A. (1996). Farmers' welfare and changing food prices: Nonparametric evidence from rice in Madagascar. American Journal of Agricultural Economics, 78(3), 656-669.

BPS. (2016). Inflasi Indonesia Menurut Kelompok Pengeluaran 2006-2015 [Indonesian inflation rate by expenditure categories, 2006-2015]. Retrieved August 24, 2016, from http://www.bps.go.id/ linkTabelStatis/view/id/901

BPS. (2017). Definisi Petani. [Definition of farmers]. Retrieved December 5, 2017, from https://sirusa.bps.go.id/index.php?r=istilah/v iew\&id $=585$

BPS. (2018). Quarterly Indonesia producer price Indices (PPI) by sector and monthly Indonesia consumers price indices (CPI). Retrieved August 29, 2018, from https://www.bps.go.id/dynamictable/2015/1 0/31/969/indeks-harga-produsen-ihpindonesia-triwulanan-menurut-sektor-2010100-2010-2018.html

Case, M., Ardiansyah, F., and Spector, E. (2007). Climate change in Indonesia: Implications for humans and nature. WWF
International Climate Change Programme, Jakarta, Indonesia.

Christensen, L. R., Jorgenson, D. W., \& Lau, L. J. (1975). Transcendental logarithmic utility functions. The American Economic Review, 65(3), 367-383.

Cox, T. L., \& Wohlgenant, M. K. (1986). Prices and quality effects in cross-sectional demand analysis. American Journal of Agricultural Economics, 68(4), 908-919.

Datt, G., \& Ravallion, M. (1998). Farm productivity and rural poverty in India. The Journal of Development Studies, 34(4), 6285.

Deaton, A. (1989). Rice prices and income distribution in Thailand: a non-parametric analysis. The Economic Journal, 99(395), 137.

Deaton, A. (1997). The analysis of household surveys: a microeconometric approach to development policy. The World Bank Publications and John Hopkins University Press, Baltimore, Maryland, USA.

Deaton, A., \& Muellbauer, J. (1980). An almost ideal demand system. The American Economic Review, 70(3), 312-326.

Deaton, A., \& Paxson, C. (1998). Economies of scale, household size, and the demand for food. Journal of Political Economy, 106(5), 897-930.

Dimova, R. (2015). The welfare impact of rising food prices. IZA World of Labor.

Dyer, C. (2007). A Suffolk farmer in the fifteenth century. Agricultural History Review, 55(1), 1-22.

Friedman, J., \& Levinsohn, J. (2002). The distributional impacts of Indonesia's financial crisis on household welfare: A "rapid response" methodology. The World Bank Economic Review, 16(3), 397-423.

Garcia, J. G. (2000). Indonesia's trade and price interventions: Pro-Java and pro-urban. Bulletin of Indonesian Economic Studies, 36(3), 93-112.

$\mathrm{Vu}, \mathrm{L}$., \& Glewwe, P. (2011). Impacts of rising food prices on poverty and welfare in Vietnam. Journal of Agricultural and Resource Economics, 14-27.

Ikhsan, M. (2003). Kemiskinan dan Harga Beras [Poverty and Rice Price]. Working Paper 
No. 3, Lembaga Penyelidikan Ekonomi dan Masyarakat Universitas Indonesia (LPEM UI).

Ivanic, M., \& Martin, W. (2008). Implications of higher global food prices for poverty in lowincome countries. The World Bank.

Lecocq, S., \& Robin, J. M. (2015). Estimating almost-ideal demand systems with endogenous regressors. Stata Journal, 15(2), 554-573.

Levinsohn, J. A., Berry, S. T., \& Friedman, J. (2003). Impacts of the Indonesian economic crisis. Price changes and the poor. In Managing currency crises in emerging markets (pp. 393-428). University of Chicago Press.

McCulloch*, N. (2008). Rice prices and poverty in Indonesia. Bulletin of Indonesian Economic Studies, 44(1), 45-64.

Mellor, J. W. (1978). Food price policy and income distribution in low-income countries. Economic Development and Cultural Change, 27(1), 1-26.

Minot, N., \& Goletti, F. (2000). Rice market liberalization and poverty in Viet Nam (Vol. 114). Intl Food Policy Res Inst.

Mitchell, D. (2008). A note on rising food prices. Policy Research Working Paper No. 4682. World Bank Washington, DC.

Moeis. (2003). Indonesia food demand system: An analysis of the impact of the economic crisis on household consumption and nutritional intake. George Washington University, Washington.

Niimi, Y. (2005). An analysis of household responses to price shocks in Vietnam: Can unit values substitute for market prices? PRUS Working Paper, No. 30, Poverty Research Unit, University of Sussex, Sussex.
Pincus, J. (1996). Class, power and agrarian Change: land and labour in rural West Java. Springer.

Rachman, H. P. S. (2001). Kajian pola konsumsi dan permintaan pangan di kawasan timur Indonesia [Reseach on consumption pattern and food demand in East Indonesia]. Institut Pertanian Bogor, Bogor.

Ravallion, M., \& Van de Walle, D. (1991). The impact on poverty of food pricing reforms: A welfare analysis for Indonesia. Journal of Policy Modeling, 13(2), 281-299.

Sayekti, A. A. S. (2008). Pola konsumsi pangan rumah tangga di wilayah historis pangan beras dan non-beras di Indonesia [Household food consumption pattern in historically rice and non-rice consuming regions in Indonesia]. Paper presented at the Seminar Nasional Dinamika Pembangunan Pertanian dan Perdesaan: Tantangan dan Peluang bagi Peningkatan Kesejahteraan Petani Bogor.

Singh, I., Squire, L., \& Strauss, J. (1986). Agricultural household models: Extensions, applications, and policy. The World Bank.

Stone, R. (1954). Linear expenditure systems and demand analysis: An application to the pattern of British demand. The Economic Journal, 64(255), 511-527.

Theil, H. (1965). The information approach to demand analysis. Econometrica: Journal of the Econometric Society, 67-87.

Warr, P., \& Yusuf, A. A. (2014). World food prices and poverty in Indonesia. Australian Journal of Agricultural and Resource Economics, 58(1), 1-21.

Wooldridge J.M. (2012). Introductory econometrics: a modern approach 5th edition. South-Western, Cengage Learning.

Disclaimer: The Journal of Indonesian Economy and Business and its Board of Editors are not responsible for any errors and flaws found in this article. The author(s) take full responsibility for their work. 


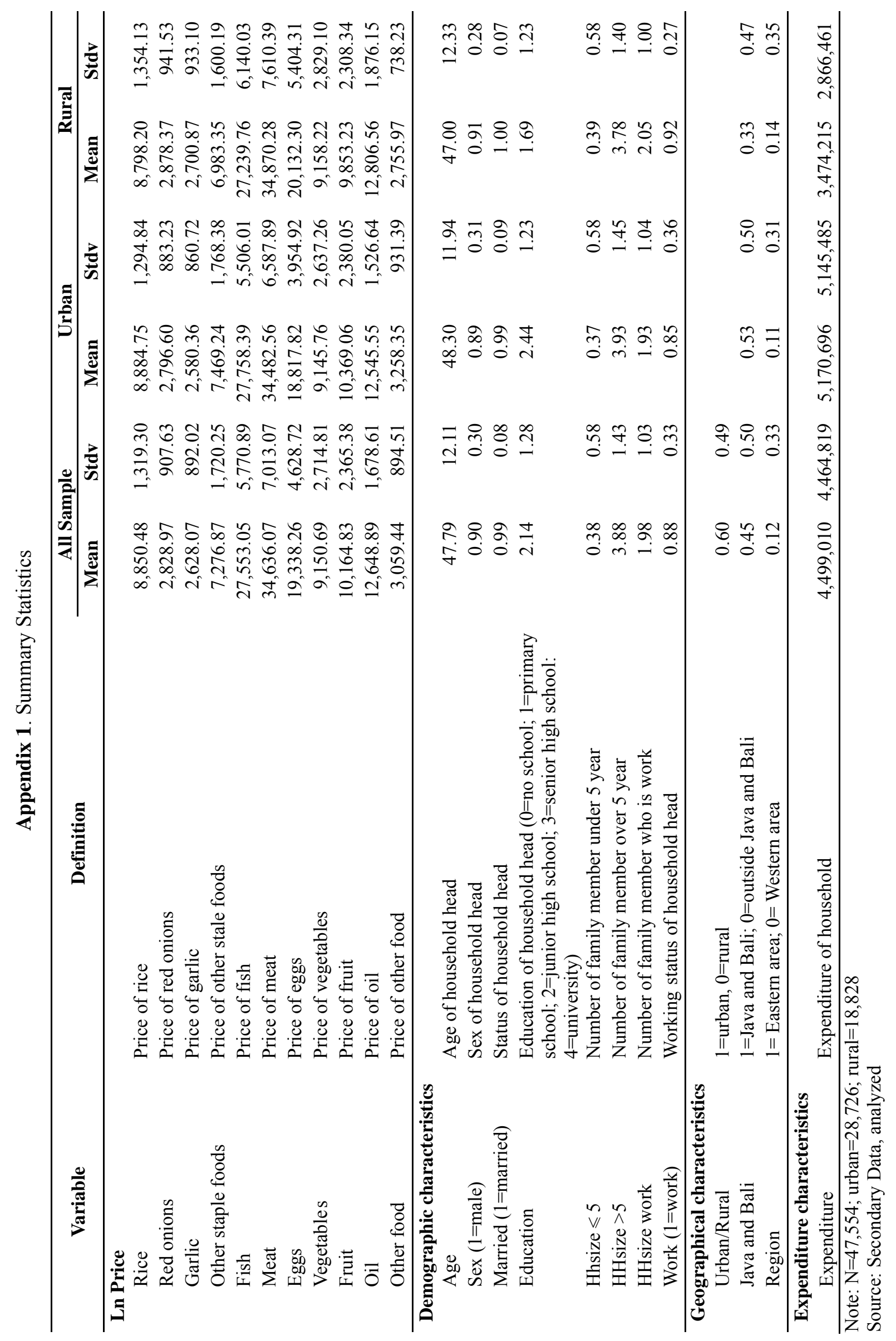




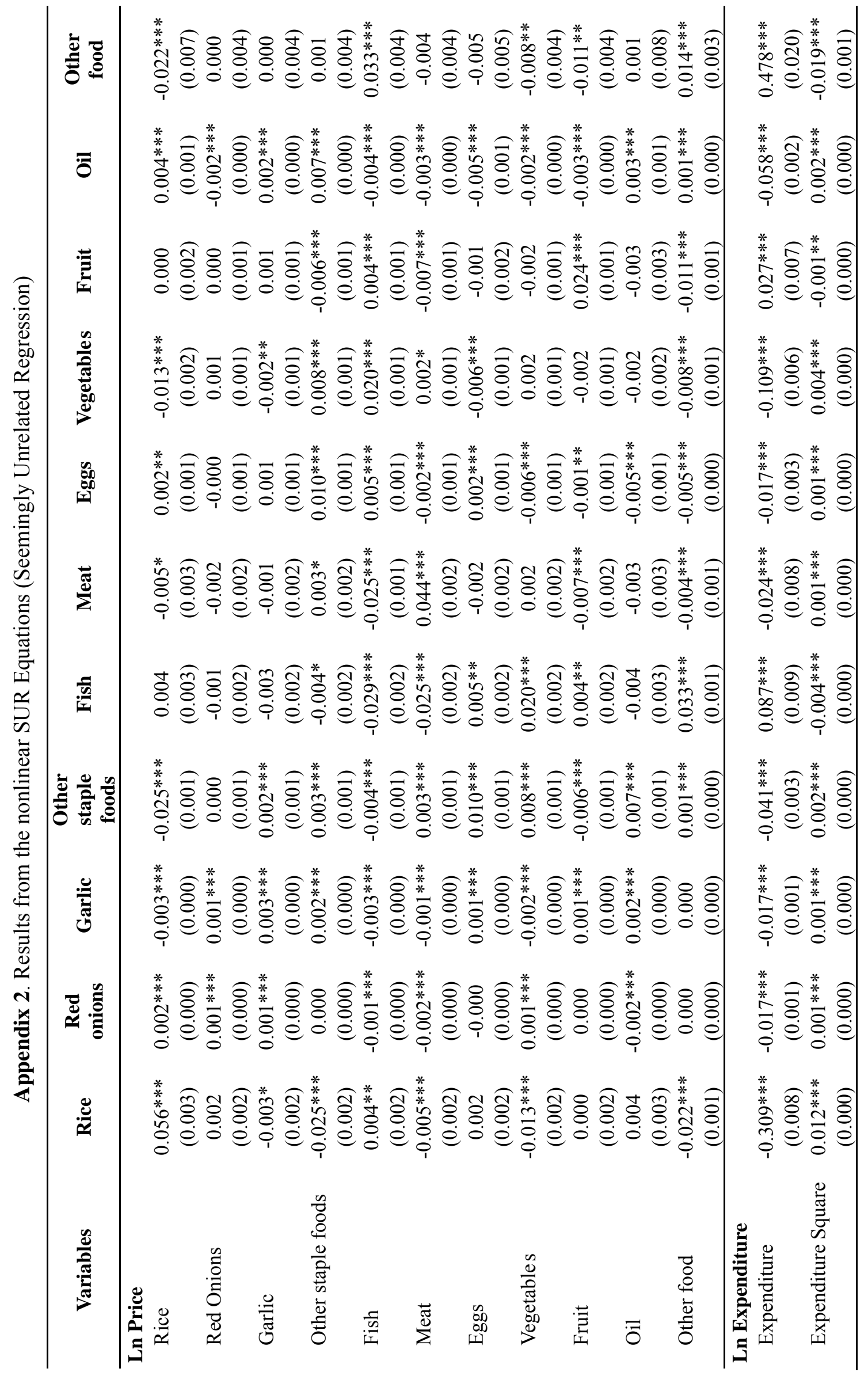




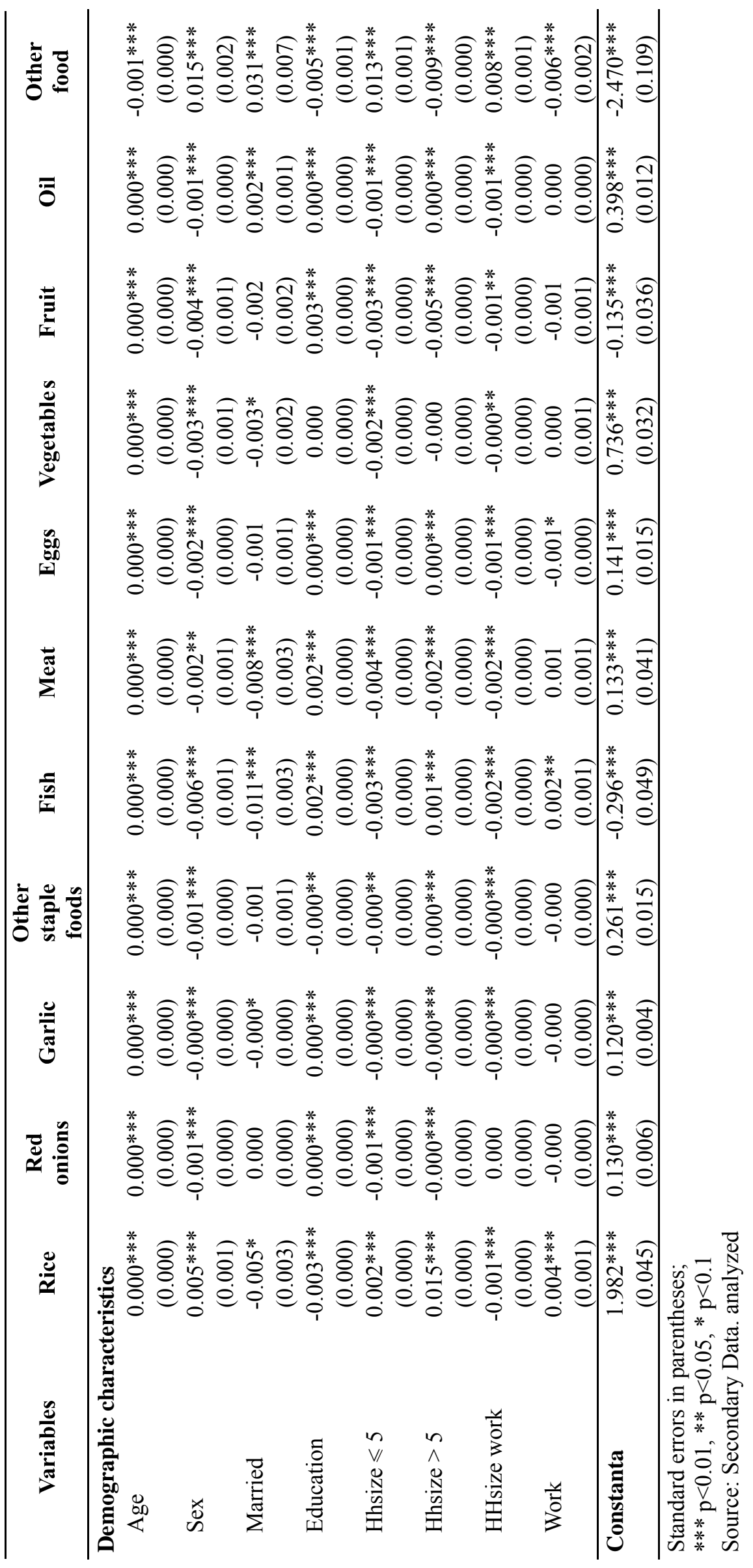

